Traveling with Sugar 



\title{
Traveling with Sugar
}

Chronicles of a Global Epidemic

\author{
Amy Moran-Thomas
}

뚜

UNIVERSITY OF CALIFORNIA PRESS 
University of California Press

Oakland, California

C 2019 by Amy Moran-Thomas

Library of Congress Cataloging-in-Publication Data

Names: Moran-Thomas, Amy, author.

Title: Traveling with sugar : chronicles of a global epidemic / Amy Moran-Thomas.

Description: Oakland, California : University of California Press, [2019] I Includes bibliographical references and index. I

Identifiers: LCCN 2OI 8054745 (print) I LCCN 20I 8056398 (ebook) I ISBN 9780520969858 (ebook)

I ISBN 978052029753 I (cloth : alk. paper)

I ISBN 9780520297548 (pbk. : alk. paper)

Subjects: LCSH: Diabetes-Belize. I Diabetics-Case studies.

Classification: LCC RA645.D5 (ebook) I LCC RA645.D5 M67 2019 (print) I DDC 6I6.4/62-dc23

LC record available at https://lccn.loc.gov/20I 8054745

Manufactured in the United States of America

$\begin{array}{llllllll}26 & 25 & 24 & 23 & 22 & 21 & 20 & \text { I9 }\end{array}$

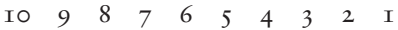


Travel with (chravl wid): to be troubled with, suffer from; have a recurring medical problem.

Travel (chravl): euphemism for being on one's death bed. -Belize Kriol dictionary

A lot of people, countrywide, in the whole entire world, here in Belize and Dangriga, are traveling with sugar ... -Anne, reflecting on diabetic sugar across three generations of her family, 20 IO 
